\title{
Nuclear Receptor Coactivator 2
}

National Cancer Institute

\section{Source}

National Cancer Institute. Nuclear Receptor Coactivator 2. NCI Thesaurus. Code C19888.

Nuclear receptor coactivator $2(1464 \mathrm{aa}, \sim 159 \mathrm{kDa})$ is encoded by the human NCOA2 gene. This protein plays a role in the regulation of steroid-mediated gene transcription. 